\title{
Garciella nitratireducens gen. nov., sp. nov., an anaerobic, thermophilic, nitrate- and thiosulfate- reducing bacterium isolated from an oilfield separator in the Gulf of Mexico
}

\author{
Elizabeth Miranda-Tello, ${ }^{1}$ Marie-Laure Fardeau, ${ }^{1}$ José Sepúlveda, ${ }^{2}$ \\ Luis Fernández, ${ }^{3}$ Jean-Luc Cayol, ${ }^{1}$ Pierre Thomas ${ }^{1}$ and Bernard Ollivier ${ }^{1}$ \\ ${ }^{1}$ IRD, UR 101 Extrêmophiles, IFR-BAIM, Universités de Provence et de la Méditerranée, ESIL \\ case 925, 163 avenue de Luminy, 13288 Marseille cedex 09, France \\ ${ }^{2}$ Laboratorio de microscopía electrónica, Centro Nacional de Investigación y Capacitación \\ Ambiental (CENICA), Universidad Autónoma Metropolitana, México, DF, Mexico \\ ${ }^{3}$ Programa de Biotecnología del Petróleo, Instituto Mexicano del Petróleo, México, DF, Mexico
}

Correspondence Bernard Ollivier ollivier@esil.univ-mrs.fr

\section{INTRODUCTION}

Oilfield environments are known to harbour an important anaerobic microbial community that includes members of domains Bacteria and Archaea (Magot et al., 2000). Several authors have reported the isolation (microbiological studies) or presence (molecular ecological studies) of microaerophiles in such ecosystems (Gevertz et al., 2000; Telang et al., 1997; Voordouw et al., 1996). Besides microaerophiles, manganese-, iron-, elemental sulfur-, sulfate-, carbon dioxide- and nitrate-reducing microorganisms inhabit oil reservoirs (Greene et al., 1997; Huu et al., 1999; Magot et al., 2000; Myhr \& Torsvik, 2000; Rees et al., 1997). Most studies have dealt with methanogens, sulfate-reducers and heterotrophs, and little attention has been paid to other microbial communities originating from this subterrestrial ecosystem. However, the addition of nitrate in oil reservoirs has been shown to stimulate the activity of indigenous nitrate-reducing, sulfide-oxidizing microaerophiles, and also that of heterotrophic denitrifiers that outcompete sulfate-reducing bacteria for energy sources (Gevertz et al., 2000; Telang et al., 1997).

The GenBank/EMBL/DDBJ accession number for the 16S rDNA sequence of strain MET79 ${ }^{\top}$ is $A Y 176772$.
Amongst microaerophilic nitrate-reducing bacteria, Gevertz et al. (2000) reported the isolation of strains of Thiomicrospira, Arcobacter and Campylobacter (phylogenetically related micro-organisms) from brine extracted at the Coleville oilfield in Canada. Nitrate-reducing anaerobes or facultative anaerobes include (i) the thermophilic, manganese- and iron-reducing bacterium Deferribacter thermophilus, isolated from the Beatrice oilfield in the North Sea (Greene et al., 1997), (ii) the thermophilic, citrate-fermenting bacterium Anaerobaculum thermoterrenum, isolated from the Redwash oilfield in Utah (Rees et al., 1997), (iii) the citrate- and succinate-oxidizing bacterium Marinobacter aquaeolei, isolated from a southern Vietnamese oil reservoir (Huu et al., 1999), and (iv) the acetate-oxidizing bacterium Denitrovibrio acetiphilus, isolated from an oil reservoir model column (Myhr \& Torsvik, 2000).

Here, we describe a novel thermophilic, heterotrophic, nitrate-reducing isolate from a water separator collecting fluids produced from different oil wells located in the SAMIII oilfield, Gulf of Mexico. It belongs to the order Clostridiales, cluster XII, and has a number of significant phenotypic, genotypic and phylogenetic differences from other members of cluster XII that justify its assignment to a 
new genus and species, Garciella nitratireducens gen. nov., sp. nov.

\section{METHODS}

Sample and strain source. Several strains were isolated from a water sample collected from a separator tank in the SAMIII oilfield in Tabasco, Gulf of Mexico. The samples were collected in sterile plastic bottles and kept at room temperature until used. The in-situ temperature of the oil-bearing formation ranged from 35 to $100^{\circ} \mathrm{C}$. The temperature in the water separator was $30-35^{\circ} \mathrm{C}$ and the salinity of the samples was $32-35 \mathrm{~g} \mathrm{l}^{-1}$.

Enrichment, isolation and growth conditions. Enrichment was performed in a medium containing $\left(1^{-1}\right.$ distilled water $) 0.3 \mathrm{~g}$ $\mathrm{K}_{2} \mathrm{HPO}_{4}, 0.3 \mathrm{~g} \mathrm{KH}_{2} \mathrm{PO}_{4}, 0.2 \mathrm{~g} \mathrm{MgSO}_{4} .7 \mathrm{H}_{2} \mathrm{O}, 0.1 \mathrm{~g} \mathrm{CaCl}_{2}, 0.1 \mathrm{~g}$ $\mathrm{KCl}, 30 \mathrm{~g} \mathrm{NaCl}, 1 \mathrm{~g} \mathrm{NH}_{4} \mathrm{Cl}, 0 \cdot 5 \mathrm{~g}$ cysteine hydrochloride, $0 \cdot 2 \mathrm{~g}$ yeast extract (Difco), $10 \mathrm{ml}$ trace mineral solution (Balch et al., 1979) and $1 \mathrm{mg}$ resazurin. The $\mathrm{pH}$ was adjusted to $7 \cdot 0$ with $10 \mathrm{M} \mathrm{KOH}$ and the medium was boiled under a stream of $\mathrm{O}_{2}$-free $\mathrm{N}_{2}$ gas and cooled to room temperature. The medium was dispensed into serum bottles $(20 \mathrm{ml})$ and Hungate tubes $(5 \mathrm{ml})$ under a stream of $\mathrm{O}_{2}$-free $\mathrm{N}_{2}$ gas, subsequently replaced by a mixture of $\mathrm{N}_{2} / \mathrm{CO}_{2}(80: 20 \%$, v/v). Vessels were autoclaved for $45 \mathrm{~min}$ at $110^{\circ} \mathrm{C}$ and, prior to inoculation, $\mathrm{Na}_{2} \mathrm{~S} .9 \mathrm{H}_{2} \mathrm{O}, \mathrm{NaHCO}_{3}$, peptone (Difco) and thiosulfate were added from sterile stock solutions to obtain respective final concentrations of $0 \cdot 04,0 \cdot 2$ and $0 \cdot 5 \%$ and $20 \mathrm{mM}$. Hydrogen (2 bars) was added in the gas phase. For enrichment, a 2-ml oil-well-water sample was inoculated into $20 \mathrm{ml}$ medium and incubated at $40{ }^{\circ} \mathrm{C}$ without agitation. Three enrichment series were performed in the same medium before isolation. Strains were isolated by repeated use of the roll-tube technique (Hungate, 1969), with medium solidified with $1.6 \%$ agar. The process of serial dilution in roll tubes was repeated at least twice in order to purify the cultures.

Determination of growth parameters. The basal medium used for characterization of the $\mathrm{pH}$, temperature and $\mathrm{NaCl}$ ranges for growth of the isolate and resistance to antibiotics was similar to the enrichment medium with the following modifications: the $\mathrm{NaCl}$ concentration was decreased to $10 \mathrm{~g} \mathrm{l}^{-1}$, glucose was added at a concentration of $20 \mathrm{mM}$ and $0 \cdot 2 \mathrm{~g} \mathrm{MgSO}_{4} .7 \mathrm{H}_{2} \mathrm{O} \mathrm{l}^{-1}$ was replaced by $1 \mathrm{~g} \mathrm{MgCl}_{2} \cdot 6 \mathrm{H}_{2} \mathrm{O}^{-1}$. The culture medium was adjusted to different $\mathrm{pH}$ values by injecting $1 \mathrm{M} \mathrm{HCl}, \mathrm{NaHCO}_{3}$ or $\mathrm{Na}_{2} \mathrm{CO}_{3}$ from $10 \%(\mathrm{w} / \mathrm{v})$ sterile anaerobic stock solutions. For studies on $\mathrm{NaCl}$ requirements, $\mathrm{NaCl}$ was weighed directly into tubes prior to dispensing the medium. The strain was subcultured at least once under the same experimental conditions prior to determination of the growth rate.

Substrate utilization tests. Substrates were tested at a final concentration of $20 \mathrm{mM}$ in basal medium or $1 \%$ for cellulose, starch and xylan or $0 \cdot 2 \%$ for peptone, bio-Trypticase and Casamino acids.

Electron acceptors and $\mathbf{H}_{\mathbf{2}} \mathbf{S}$ production. To test for electron acceptors, sodium thiosulfate $(20 \mathrm{mM})$, sodium sulfate $(20 \mathrm{mM})$, sodium fumarate $(20 \mathrm{mM})$, sodium sulfite $(5 \mathrm{mM})$, elemental sulfur $(1 \%)$, sodium nitrate $(10 \mathrm{mM})$ and sodium nitrite $(5 \mathrm{mM})$ were added individually to the medium. The use of electron acceptors was evaluated by measuring $\mathrm{OD}_{580}$ and $\mathrm{H}_{2} \mathrm{~S}$, succinate, ammonium or nitrite production. Nitrate reduction was tested in the absence of ammonium chloride as nitrogen source.

Antibiotic susceptibility. The sensitivity of the isolate to ampicillin, chloramphenicol, kanamycin, rifampicin and vancomycin was tested at $10,25,50$ and $100 \mu \mathrm{g} \mathrm{ml}^{-1}$. Controls were performed with ethanol and DMSO (respectively solvents for chloramphenicol and rifampicin). Growth was monitored by measuring $\mathrm{OD}_{580}$ and by microscopic observations.
Sporulation test and oxygen susceptibility. The presence of spores was analysed by phase-contrast microscopic observations of young and old cultures and pasteurization tests performed at 80,90 and $100{ }^{\circ} \mathrm{C}$ for 10 and $20 \mathrm{~min}$. The effect of $\mathrm{O}_{2}$ on growth was determined in Hungate tubes containing basal medium supplemented with $20 \mathrm{mM}$ glucose. After inoculation, $20 \mathrm{ml}$ sterile air was added to the gas phase. The cultures were incubated at $55^{\circ} \mathrm{C}$ under agitation (150 r.p.m.). Growth was monitored by turbidity measurements $\left(\mathrm{OD}_{580}\right)$. Experiments were conducted in duplicate and repeated at least twice.

Analytical techniques. Unless otherwise indicated, duplicate culture tubes were used throughout these studies. Growth was measured at $580 \mathrm{~nm}$ using a UV-Visible spectrophotometer 50 Scan (Varian). Sulfide was determined photometrically as colloidal $\mathrm{CuS}$ by using the method of Cord-Ruwisch (1985). Ammonium was detected by the Nessler method. Fermentation products were determined by HPLC using a pump (Spectra Series P100; Thermo Separation Products), an automatic sampler (Spectra Series AS100), an Aminex HPX $87 \mathrm{H}$ column $(300 \times 7 \cdot 8 \mathrm{~mm})$ (Bio-Rad), a differential refractometer detector (Spectra System RI-150) and an integrator (Azur Microsoft). An aliquot of $20 \mu \mathrm{l}$ cell-free supernatant was injected into the column, which was maintained at $37^{\circ} \mathrm{C}$. A solution of $0.01 \mathrm{M} \mathrm{H}_{2} \mathrm{SO}_{4}$ was used as solvent at a flow rate of $0.6 \mathrm{ml} \mathrm{min}{ }^{-1}$. The presence of L-alanine as an end product of sugar metabolism was determined enzymically at $340 \mathrm{~nm}$ as described previously (Fardeau et al., 1997).

Light and electron microscopy. Morphological characteristics of isolates were observed with a phase microscope (Nikon). For scanning electron microscopy studies, cells were stained with osmium tetroxide, prepared as described by Bozzola \& Russell (1991) and observed in a JEOL-5900 low-vacuum electron microscope at an accelerating voltage of $10 \mathrm{kV}$. For transmission electron microscopy studies, cells were negatively stained with sodium phosphotungstate and prepared and observed as described by Koussémon et al. (2001).

Determination of $\mathrm{G}+\mathrm{C}$ content and $16 \mathrm{~S}$ rDNA sequence analysis. The $\mathrm{G}+\mathrm{C}$ content of DNA was determined at the DSMZ by using HPLC as described by Mesbah et al. (1989). Non-methylated lambda DNA (Sigma) was used as the standard. The 16S rRNA gene of the isolate was amplified by adding $2.5 \mu \mathrm{l}$ cell culture to a thermocycler microtube containing $5 \mu \mathrm{l} 10 \times$ Taq buffer (Promega), $3 \mu \mathrm{l} 25 \mathrm{mM} \mathrm{MgCl}_{2}, 0.5 \mu \mathrm{l} 25 \mathrm{mM}$ dNTPs, $0.5 \mu \mathrm{l} 100 \mathrm{nM}$ primers, $37.5 \mu \mathrm{l}$ sterile distilled water and $0.5 \mu \mathrm{l} 5 \mathrm{U}$ Taq polymerase $\mu l^{-1}$ (Promega). The universal primers Fdl (5'-AGAGTTTGATCCTGGCTCAG-3', positions 8-28) and Rd1 (5'-AAGGAGGTGATCCAGCC-3', positions 1547-1531, MWG) (Escherichia coli numbering) were used to obtain the PCR product (Winker \& Woese, 1991). PCR was performed by an initial denaturation at $96^{\circ} \mathrm{C}$ for $3 \mathrm{~min}$ followed by 30 cycles of annealing at $57 \cdot 1{ }^{\circ} \mathrm{C}$ for $30 \mathrm{~s}$, extension at $72{ }^{\circ} \mathrm{C}$ for $2 \mathrm{~min}$ and denaturation at $96^{\circ} \mathrm{C}$ for $30 \mathrm{~s}$ and, finally, an extension cycle of $72{ }^{\circ} \mathrm{C}$ for $7 \mathrm{~min}$. The amplified fragment contained 1471 nucleotides. PCR products were purified with a QIAquick gel extraction kit. Direct sequencing of the PCR product was performed by Genome Express. The new sequence was aligned to a full-length consensus 16S rDNA sequence, assembled and checked for accuracy manually, using the alignment editor BioEdit version 5.0.9 (Hall, 1999). These were compared with other sequences in GenBank (Benson et al., 1999) and the RDP (Maidak et al., 2001) using BLAST (Altschul et al., 1997) to identify the closest relatives. Positions of sequence and alignment ambiguity were omitted and pairwise evolutionary distances based on 1267 unambiguous nucleotides were computed by using the method of Jukes \& Cantor (1969). A dendrogram was constructed using the neighbour-joining method (Saitou \& Nei, 1987). Confidence in the tree topology was determined by using 100 bootstrapped trees (Felsenstein, 1985). 


\section{RESULTS AND DISCUSSION}

Anaerobes have always been considered as the dominant indigenous micro-organisms of the oilfield ecosystem (Magot et al., 2000). Amongst these, the occurrence of methanogenic, sulfate-reducing and heterotrophic bacteria belonging to the families Thermotogaceae and Thermoanaerobiaceae has been established from various oil reservoirs throughout the world (Magot et al., 2000). Microaerophilic nitrate-reducing bacteria have been shown to be helpful in oil reservoirs because they oxidize sulfurcontaining compounds and reduce $\mathrm{H}_{2} \mathrm{~S}$ production (Telang et al., 1997). However, few studies have reported the isolation of such bacteria from oil production waters (Gevertz et al., 2000). Besides microaerophilic nitratereducing bacteria, few studies have provided evidence of the existence of anaerobic nitrate-reducers in oil reservoirs (Greene et al., 1997; Myhr \& Torsvik, 2000; Rees et al., 1997). Here, we report a novel anaerobic, nitrate-reducing bacterium isolated from an oilfield separator in the Gulf of Mexico. Enrichment cultures were positive after incubation at $40^{\circ} \mathrm{C}$ for 15 days. Microscopic examination revealed the presence of motile, rod-shaped bacteria. Round, slightly black-coloured colonies ( $2 \mathrm{~mm}$ diameter) developed on roll tubes after 1 week. Single colonies were picked and serially diluted and reinoculated in roll tubes three times before cultures were considered pure. Several strains similar in morphology were isolated from the oil reservoir, and one strain, designated MET79 ${ }^{\mathrm{T}}$, was used for further characterization.

Cells of strain MET79 $^{\mathrm{T}}$ were straight rods, $0 \cdot 5-0 \cdot 7 \times$ $1 \cdot 4-2 \cdot 8 \mu \mathrm{m}$ in size (Fig. 1a, b), motile with a subpolar flagellum. Spherical and terminal spores appeared in old cultures. Irregular gas vacuoles were sometimes observed (Fig. 1a). Ultrathin sections of cells showed a Grampositive-type cell wall composed of a thick $(17 \mathrm{~nm})$ and homogeneous S-layer (Fig. 1c). Strain MET79 ${ }^{\mathrm{T}}$ grew at temperatures ranging from 25 to $60^{\circ} \mathrm{C}$, with optimum growth at $55^{\circ} \mathrm{C}$. Growth occurred at initial $\mathrm{pH}$ values between $5 \cdot 5$ and $9 \cdot 0$ at $55^{\circ} \mathrm{C}$ and the optimum was $\mathrm{pH} 7 \cdot 5$. The isolate grew in the presence of $\mathrm{NaCl}$ concentrations ranging from 0 to $10 \%$, with an optimum $\mathrm{NaCl}$ concentration of $1 \%$ at pH $7 \cdot 5$ and $55^{\circ} \mathrm{C}$. Strain MET79 $9^{\mathrm{T}}$ grew in the presence of up to $25 \mu \mathrm{g}$ kanamycin and chloramphenicol $\mathrm{ml}^{-1}$ and $100 \mu \mathrm{g}$ ampicillin $\mathrm{ml}^{-1}$, but not in the presence of $10 \mu \mathrm{g}$ vancomycin or rifampicin $\mathrm{ml}^{-1}$. Yeast extract was required for growth. Vitamins or bio-Trypticase could not replace yeast extract. Strain $M E T 79^{T}$ fermented the following compounds: cellobiose, fructose, galactose, glucose, lactose, maltose, mannose, ribose, sucrose, D-xylose, glycerol, mannitol, fumarate, lactate, malate, pyruvate and Casamino acids. One mol glucose was fermented into 1.5 mol lactate as the major end product, with minor amounts of acetate $\left[0.03 \mathrm{~mol}(\mathrm{~mol} \text { glucose consumed })^{-1}\right]$ and butyrate $\left[0 \cdot 2 \mathrm{~mol}(\mathrm{~mol} \text { glucose consumed })^{-1}\right]$, and into $\mathrm{H}_{2}\left[0 \cdot 3 \mathrm{~mol}\right.$ (mol glucose consumed) $\left.{ }^{-1}\right]$ and $\mathrm{CO}_{2}$. The following compounds were not used: arabinose, raffinose, rhamnose, starch, cellulose, xylan, acetate,
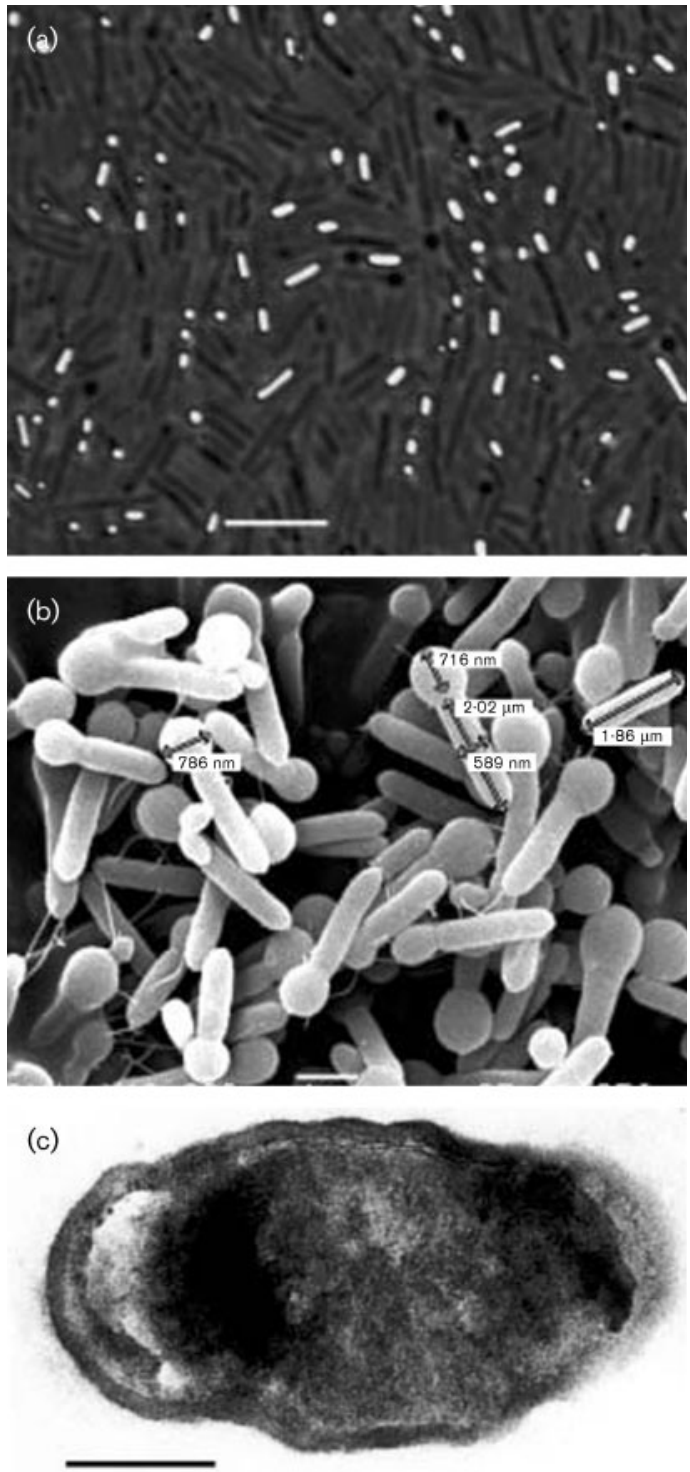

Fig. 1. Micrographs of strain MET79 ${ }^{\top}$. (a) Phase-contrast micrograph of cells grown in optimal conditions in reduced medium in the presence of air, showing gas vacuoles. Bar, $2 \mu \mathrm{m}$. (b) Scanning electron microscopy after thermal stress, showing spherical, terminal spores swelling the cells and a subpolar flagellum. Bar, $1 \mu \mathrm{m}$. (c) Electron micrograph of an ultrathin section showing a Gram-positive-type cell wall with a thick layer. Bar, $0 \cdot 2 \mu \mathrm{m}$.

butyrate, propionate, methanol, ethanol, butanol, propanol, formate, methylamine, $p$-coumaric acid, ferulic acid, peptone, bio-Trypticase and $\mathrm{H}_{2}$. Strain $\mathrm{MET79}^{\mathrm{T}}$ reduced thiosulfate to $\mathrm{H}_{2} \mathrm{~S}$ and nitrate to ammonium. The other electron acceptors tested were not used. Growth was enhanced in the presence of thiosulfate or nitrate. Strain MET79 $^{\mathrm{T}}$ grew under anaerobic conditions. The $\mathrm{G}+\mathrm{C}$ content of strain MET79 $^{\mathrm{T}}$ was $30.9 \mathrm{~mol} \%$. 16S rDNA sequence analysis revealed that strain $\mathrm{MET79}^{\mathrm{T}}$ was a member of the order Clostridiales, cluster XII, as defined 


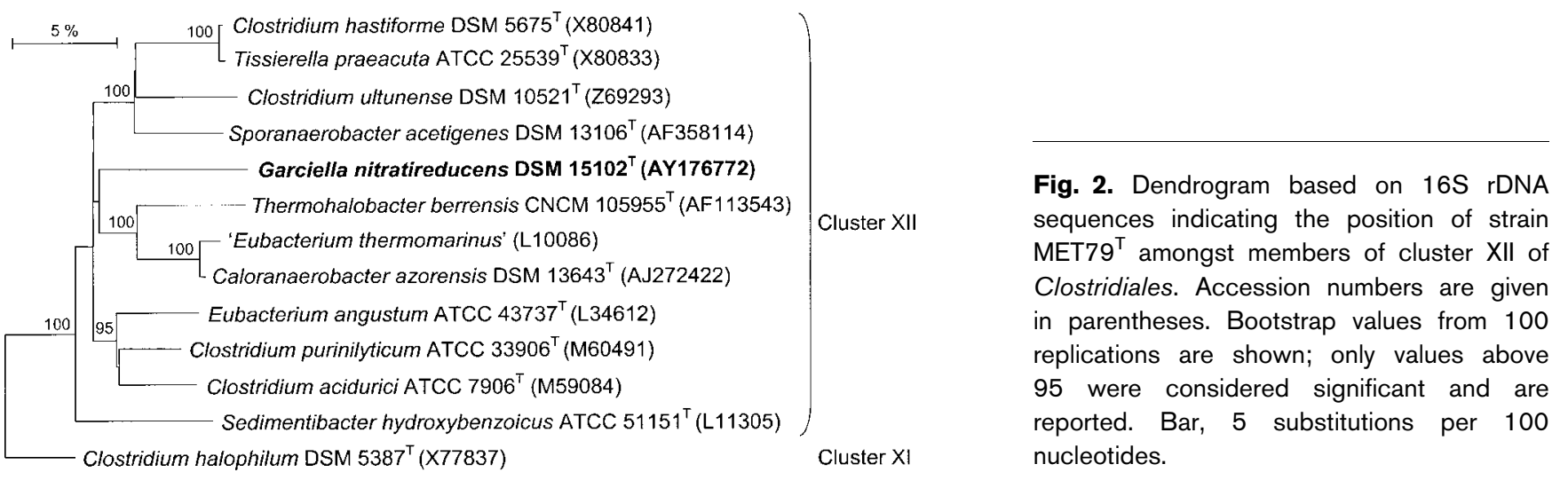

by Collins et al. (1994), and its closest phylogenetic relative was Caloranaerobacter azorensis (Wery et al., 2001), family Clostridiaceae ( $88.7 \%$ similarity). Fig. 2 presents a dendrogram generated by the neighbour-joining method (Saitou \& Nei, 1987).

Three species belonging to the order Clostridiales have so far been isolated from oil wells. They include two mesophiles, Dethiosulfovibrio peptidovorans, family Syntrophomonadaceae (Magot et al., 1997), and Fusibacter paucivorans, family Peptostreptococcaceae (Ravot et al., 1999), and the thermophilic Anaerobaculum thermoterrenum, family Syntrophomonadaceae (Rees et al., 1997). Dethiosulfovibrio peptidovorans is peripherally related to cluster V, consisting of the family Thermoanaerobiaceae (Magot et al., 1997), whereas Fusibacter paucivorans grouped with members of cluster XI (Ravot et al., 1999). Similarly to strain MET79 ${ }^{\mathrm{T}}$, Anaerobaculum thermoterrenum also reduced nitrate, but the latter forms a branch that is approximately equidistant from Dictyoglomus thermophilum and members of Thermoanaerobacter (Rees et al., 1997). In addition to phylogenetic differences between strain $\mathrm{MET}_{79^{\mathrm{T}}}$ and these three species, there are also numerous phenotypic and genotypic differences (Table 1). Two other anaerobes isolated from oilfield ecosystems were reported to reduce nitrate, Deferribacter thermophilus and Denitrovibrio acetiphilus (Greene et al., 1997; Myhr \& Torsvik, 2000). Neither bacterium belongs to the Clostridiales. The organism that is phylogenetically most closely related to Deferribacter thermophilus is Flexistipes sinusarabici (sequence similarity $88 \%$ ), whereas the closest relative of Denitrovibrio acetiphilus is Geovibrio ferrireducens (sequence similarity $86.9 \%$ ). In contrast to strain MET79 $^{\mathrm{T}}$, Deferribacter thermophilus and Denitrovibrio acetiphilus are specialized in the oxidation of organic acids and are unable to ferment sugars (Greene et al., 1997; Myhr \& Torsvik, 2000). Within cluster XII, strain MET79 $^{\mathrm{T}}$ has Caloranaerobacter azorensis (Wery et al., 2001) as its closest phylogenetic relative (sequence similarity $88 \cdot 7 \%$ ). Strain MET79 $^{\mathrm{T}}$ differs from Caloranaerobacter azorensis, isolated from a deep-sea hydrothermal vent, by its cell-wall structure. Furthermore, Caloranaerobacter azorensis is a non-sporulating bacterium that does not reduce thiosulfate or nitrate but reduces elemental sulfur. The end products of glucose metabolism by these two bacteria are also very different (Table 1). The two strains also differ in the ranges and optima of growth conditions, in the range of substrates used and in the $\mathrm{G}+\mathrm{C}$ content of DNA (Table 1).

Interestingly, strain MET79 ${ }^{\mathrm{T}}$ reduced thiosulfate to sulfide, as do several other heterotrophic anaerobic isolates from the oilfield ecosystem (Fardeau et al., 1997, 2000; Magot et al., 1997, 2000; Ravot et al., 1995a, b, 1999). Such activity might result in increasing biocorrosion processes in situ (Magot et al., 1997). In light of its phenotypic, genotypic and phylogenetic characteristics, strain MET79 ${ }^{\mathrm{T}}$ represents a novel genus within cluster XII of the order Clostridiales that we propose to name Garciella nitratireducens gen. nov., sp. nov.

\section{Description of Garciella gen. nov.}

Garciella (Gar.ci.el'la. L. dim. ending -ella; N.L. fem. n. Garciella named in honour of the French microbiologist Jean-Louis Garcia, for his important contribution to the taxonomy of anaerobes).

Cells are straight rods with a Gram-positive-type cell wall. Terminal spores are formed. Growth is strictly anaerobic. Moderately thermophilic, fermentative member of the domain Bacteria, phylum Firmicutes, cluster XII of the order Clostridiales, family Clostridiaceae. Carbohydrates and organic acids serve as fermentable substrates. The type species is Garciella nitratireducens.

\section{Description of Garciella nitratireducens sp. nov.}

Garciella nitratireducens (ni.tra.ti.re.du'cens. N.L. n. nitratum nitrate; L. v. reduco to draw backwards, bring back to a state or condition; N.L. part. adj. nitratireducens nitrate-reducing).

Displays the following properties in addition to those given in the genus description. Cells $(0.5-0.7 \times 1 \cdot 4-2.8 \mu \mathrm{m})$ occur singly or in pairs and possess one subpolar flagellum. Terminal spores appear in old cultures. Round colonies ( $2 \mathrm{~mm}$ diameter) develop in roll tubes after 1 week of incubation at $55^{\circ} \mathrm{C}$. Chemo-organotrophic. The optimum temperature for growth is $55^{\circ} \mathrm{C}$ at $\mathrm{pH} 7 \cdot 5$; temperature 
Table 1. Characteristics that distinguish between strain $M E T 79^{\top}$, Caloranaerobacter azorensis and other members of the Clostridiales isolated from oil wells

Strain/species: 1, strain ${\mathrm{MET} 79^{\mathrm{T}}} ; 2$, Caloranaerobacter azorensis (data from Wery et al., 2001); 3, Anaerobaculum thermoterrenum (Rees et al., 1997); 4, Dethiosulfovibrio peptidovorans (Magot et al., 1997); 5, Fusibacter paucivorans (Ravot et al., 1999). ND, Not determined.

\begin{tabular}{|c|c|c|c|c|c|}
\hline Characteristic & 1 & 2 & 3 & 4 & 5 \\
\hline \multicolumn{6}{|l|}{ Temperature for growth $\left({ }^{\circ} \mathrm{C}\right)$ : } \\
\hline Range & $25-60$ & $45-65$ & $28-60$ & $20-45$ & $20-45$ \\
\hline Optimum & 55 & 65 & 55 & 42 & 37 \\
\hline \multicolumn{6}{|l|}{$\mathrm{pH}$ for growth: } \\
\hline Range & $5 \cdot 5-9 \cdot 0$ & $5 \cdot 5-9 \cdot 0$ & $5 \cdot 5-8 \cdot 6$ & $5 \cdot 5-8 \cdot 8$ & $5 \cdot 7-8 \cdot 0$ \\
\hline Optimum & $7 \cdot 5$ & $7 \cdot 0$ & $7 \cdot 0-7 \cdot 6$ & $7 \cdot 0$ & $7 \cdot 3$ \\
\hline \multicolumn{6}{|c|}{$\mathrm{NaCl}$ concentration for growth (\%): } \\
\hline Range & $0-10$ & $0 \cdot 6-6 \cdot 5$ & $0-2$ & $0 \cdot 5-9 \cdot 5$ & $0-10$ \\
\hline Optimum & 1 & 2 & 1 & 3 & $0-3$ \\
\hline DNA G $+C$ content $(\mathrm{mol} \%)$ & $30 \cdot 9$ & $26-28$ & 44 & 56 & 43 \\
\hline Reduction of $\mathrm{S}^{0}$ & - & + & + & + & + \\
\hline Reduction of $\mathrm{S}_{2} \mathrm{O}_{3}^{2-}$ & + & - & + & + & + \\
\hline Flagella & 1, Subpolar & ND & - & Lateral & Peritrichous \\
\hline \multicolumn{6}{|l|}{ Substrates used: } \\
\hline Cellobiose & + & - & ND & - & + \\
\hline Fructose & + & + & + & - & + \\
\hline Galactose & + & + & ND & - & - \\
\hline Glucose & + & + & + & - & + \\
\hline Lactose & + & - & ND & - & - \\
\hline Maltose & + & - & ND & - & - \\
\hline Mannose & + & ND & + & - & - \\
\hline Ribose & + & + & ND & - & + \\
\hline Starch & - & + & + & - & - \\
\hline Xylose & + & + & ND & - & - \\
\hline Glycerol & + & ND & + & - & - \\
\hline Mannitol & + & - & ND & - & + \\
\hline Pyruvate & + & + & + & - & - \\
\hline Xylan & - & + & ND & - & ND \\
\hline \multicolumn{6}{|c|}{$\begin{array}{l}\text { Diagnostic fermentation products } \\
\text { from glucose: }\end{array}$} \\
\hline Lactate & + & ND & - & - & - \\
\hline Acetate & + & + & + & - & + \\
\hline Butyrate & + & ND & - & - & + \\
\hline
\end{tabular}

range $25-60{ }^{\circ} \mathrm{C}$. The optimum $\mathrm{pH}$ is $7 \cdot 5$; growth occurs between $\mathrm{pH} 5 \cdot 5$ and $9 \cdot 0$. Halotolerant, growing in the presence of up to $10 \% \mathrm{NaCl}$ with an optimum at $1 \%$. Yeast extract is required for growth and cannot be replaced by vitamins. Ferments cellobiose, fructose, galactose, glucose, lactose, maltose, mannose, ribose, sucrose, D-xylose, glycerol, mannitol, fumarate, lactate, malate, pyruvate and Casamino acids. Arabinose, raffinose, rhamnose, starch, cellulose, xylan, acetate, butyrate, propionate, methanol, ethanol, butanol, propanol, formate, methylamine, $p$-coumaric acid, ferulic acid, peptone, bio-Trypticase and $\mathrm{H}_{2}$ are not used. Lactate, acetate, butyrate, $\mathrm{H}_{2}$ and $\mathrm{CO}_{2}$ are produced during glucose fermentation. Thiosulfate is reduced to sulfide and nitrate to ammonium; elemental sulfur, sulfite, sulfate, fumarate and nitrite are not used as electron acceptors. Thiosulfate or nitrate enhance growth. Can grow in the presence of $25 \mu \mathrm{g}$ kanamycin or chloramphenicol $\mathrm{ml}^{-1}$ and $100 \mu \mathrm{g}$ ampicillin $\mathrm{ml}^{-1}$ but not in the presence of $10 \mu \mathrm{g}$ vancomycin or rifampicin $\mathrm{ml}^{-1}$. The $\mathrm{G}+\mathrm{C}$ content of the DNA of the type strain is $30.9 \mathrm{~mol} \%$ (HPLC).

The type strain, MET79 ${ }^{\mathrm{T}}\left(=\mathrm{DSM} 15102^{\mathrm{T}}=\mathrm{CIP} 107615^{\mathrm{T}}\right)$, was isolated from an oilfield separator in the Gulf of Mexico.

\section{ACKNOWLEDGEMENTS}

Financial support to E. M.-T. from Consejo Nacional de Ciencia y Tecnología (CONACyT), Secretaría de Educación Pública (SEP) of 
Mexico and Société Française d'Exportation des Ressources Educatives (SFERE) is acknowledged. Many thanks to L. Casalot and D. Alazard for valuable advice and P. Roger for improving the manuscript.

\section{REFERENCES}

Altschul, S. F., Madden, T. L., Schäffer, A. A., Zhang, J., Zhang, Z., Miller, W. \& Lipman, D. J. (1997). Gapped BLAST and PSI-BLAST: a new generation of protein database search programs. Nucleic Acids Res 25, 3389-3402.

Balch, W. E., Fox, G. E., Magrum, R. J., Woese, C. R. \& Wolfe, R. S. (1979). Methanogens: reevaluation of a unique biological group. Microbiol Rev 43, 260-296.

Benson, D. A., Boguski, M. S., Lipman, D. J., Ostell, J., Ouellette, B. F. F., Rapp, B. A. \& Wheeler, D. L. (1999). GenBank. Nucleic Acids Res 27, 12-17.

Bozzola, J. J. \& Russell, L. D. (1991). Electron microscopy. In Principles and Techniques for Biologists, pp. 40-61. Boston: Jones \& Bartlett.

Collins, M. D., Lawson, P. A., Willems, A., Cordoba, J. J., FernandezGarayzabal, J., Garcia, P., Cai, J., Hippe, H. \& Farrow, J. A. E. (1994). The phylogeny of the genus Clostridium: proposal of five new genera and eleven new species combinations. Int J Syst Bacteriol 44, 812-826.

Cord-Ruwisch, R. (1985). A quick method for the determination of dissolved and precipitated sulfides in cultures of sulfate-reducing bacteria. J Microbiol Methods 4, 33-36.

Fardeau, M.-L., Ollivier, B., Patel, B. K. C., Magot, M., Thomas, P., Rimbault, A., Rocchiccioli, F. \& Garcia, J.-L. (1997). Thermotoga hypogea sp. nov., a xylanolytic, thermophilic bacterium from an oilproducing well. Int J Syst Bacteriol 47, 1013-1019.

Fardeau, M.-L., Magot, M., Patel, B. K. C., Thomas, P., Garcia, J.-L. \& Ollivier, B. (2000). Thermoanaerobacter subterraneus sp. nov., a novel thermophile isolated from oilfield water. Int J Syst Evol Microbiol 50, 2141-2149.

Felsenstein, J. (1985). Confidence limits on phylogenies: an approach using the bootstrap. Evolution 39, 783-791.

Gevertz, D., Telang, A. J., Voordouw, G. \& Jenneman, G. E. (2000). Isolation and characterization of strains CVO and FWKO B, two novel nitrate-reducing, sulfide-oxidizing bacteria isolated from oil field brine. Appl Environ Microbiol 66, 2491-2501.

Greene, A. C., Patel, B. K. C. \& Sheehy, A. J. (1997). Deferribacter thermophilus gen. nov., sp. nov., a novel thermophilic manganeseand iron-reducing bacterium isolated from a petroleum reservoir. Int J Syst Bacteriol 47, 505-509.

Hall, T. A. (1999). BioEdit: a user-friendly biological sequence alignment editor and analysis program for Windows 95/98 NT. Nucleic Acids Symp Ser 41, 95-98.

Hungate, R. E. (1969). A roll-tube method for the cultivation of strict anaerobes. Methods Microbiol 3B, 117-132.

Huu, N. B., Denner, E. B. M., Ha, D. T. C., Wanner, G. \& Stan-Lotter, H. (1999). Marinobacter aquaeolei sp. nov., a halophilic bacterium isolated from a Vietnamese oil-producing well. Int J Syst Bacteriol 49, 367-375.

Jukes, T. H. \& Cantor, C. R. (1969). Evolution of protein molecules. In Mammalian Protein Metabolism, pp. 211-232. Edited by H. N. Munro. New York: Academic Press.
Koussémon, M., Combet-Blanc, Y., Patel, B. K. C., Cayol, J.-L., Thomas, P., Garcia, J.-L. \& Ollivier, B. (2001). Propionibacterium microaerophilum sp. nov., a microaerophilic bacterium isolated from olive mill wastewater. Int J Syst Evol Microbiol 51, 1373-1382.

Magot, M., Ravot, G., Campaignolle, X., Ollivier, B., Patel, B. K. C., Fardeau, M.-L., Thomas, P., Crolet, J.-L. \& Garcia, J.-L. (1997). Dethiosulfovibrio peptidovorans gen. nov., sp. nov., a new anaerobic, slightly halophilic, thiosulfate-reducing bacterium from corroding offshore oil wells. Int J Syst Bacteriol 47, 818-824.

Magot, M., Ollivier, B. \& Patel, B. K. C. (2000). Microbiology of petroleum reservoirs. Antonie van Leeuwenhoek 77, 103-116.

Maidak, B. L., Cole, J. R. \& Lilburn, T. G. (2001). The RDP-II (Ribosomal Database Project). Nucleic Acids Res 29, 173-174.

Mesbah, M., Premachandran, U. \& Whitman, W. B. (1989). Precise measurement of the $\mathrm{G}+\mathrm{C}$ content of deoxyribonucleic acid by high-performance liquid chromatography. Int J Syst Bacteriol 39, 159-167.

Myhr, S. \& Torsvik, T. (2000). Denitrovibrio acetiphilus, a novel genus and species of dissimilatory nitrate-reducing bacterium isolated from an oil reservoir model column. Int J Syst Evol Microbiol 50, 1611-1619.

Ravot, G., Magot, M., Fardeau, M.-L., Patel, B. K. C., Prensier, G., Egan, A., Garcia, J.-L. \& Ollivier, B. (1995a). Thermotoga elfii sp. nov., a novel thermophilic bacterium from an African oil-producing well. Int J Syst Bacteriol 45, 308-314.

Ravot, G., Ollivier, B., Magot, M., Patel, B. K. C., Crolet, J.-L., Fardeau, M.-L. \& Garcia, J.-L. (1995b). Thiosulfate reduction, an important physiological feature shared by members of the order Thermotogales. Appl Environ Microbiol 61, 2053-2055.

Ravot, G., Magot, M., Fardeau, M.-L., Patel, B. K. C., Thomas, P., Garcia, J.-L. \& Ollivier, B. (1999). Fusibacter paucivorans gen. nov., sp. nov., an anaerobic, thiosulfate-reducing bacterium from an oilproducing well. Int J Syst Bacteriol 49, 1141-1147.

Rees, G. N., Patel, B. K. C., Grassia, G. S. \& Sheehy, A. J. (1997) Anaerobaculum thermoterrenum gen. nov., sp. nov., a novel, thermophilic bacterium which ferments citrate. Int J Syst Bacteriol 47, 150-154.

Saitou, N. \& Nei, M. (1987). The neighbor-joining method: a new method for reconstructing phylogenetic trees. Mol Biol Evol 4, 406-425.

Telang, A. J., Ebert, S., Foght, J. M., Westlake, D. W. S., Jenneman, G. E., Gevertz, D. \& Voordouw, G. (1997). Effect of nitrate injection on the microbial community in an oil field as monitored by reverse sample genome probing. Appl Environ Microbiol 63, 1785-1793.

Voordouw, G., Armstrong, S. M., Reimer, M. F., Fouts, B., Telang, A. J., Shen, Y. \& Gevertz, D. (1996). Characterization of $16 \mathrm{~S}$ rRNA genes from oil field microbial communities indicates the presence of a variety of sulfate-reducing, fermentative, and sulfide-oxidizing bacteria. Appl Environ Microbiol 62, 1623-1629.

Wery, N., Moricet, J.-M., Cueff, V., Jean, J., Pignet, P., Lesongeur, F., Cambon-Bonavita, M.-A. \& Barbier, G. (2001). Caloranaerobacter azorensis gen. nov., sp. nov., an anaerobic thermophilic bacterium isolated from a deep-sea hydrothermal vent. Int J Syst Evol Microbiol 51, 1789-1796.

Winker, S. \& Woese, C. R. (1991). A definition of the domain Archaea, Bacteria and Eucarya in terms of small subunit ribosomal RNA characteristics. Syst Appl Microbiol 13, 161-165. 